Research, part of a Special Feature on Social Learning in Water Resources Management

\title{
Cultural Factors as Co-Determinants of Participation in River Basin Management
}

\author{
Bert Enserink $^{1}$, Mita Patel $^{2}$, Nicole Kranz $^{3}$, and Josefina Maestu ${ }^{4}$
}

\begin{abstract}
Finding a place for public participation in the policies and practices of European river basin management planning is a challenge for the authorities in the participating countries and territories. Understanding the relation between national culture, the historical and political differences in the respective countries, and their practical experience with participation is considered important to support the implementation of the EU Water Framework Directive. Knowledge and understanding of this relation is important to provide a context and basis from which new participatory practices can be designed and experiences evaluated and to identify conditions necessary for social learning. Within the context of the HarmoniCOP project, such a study was undertaken in the form of a National Approach and Background study, which examined and evaluated both historical and recent experiences that exist across Europe in relation to public participation and water management as it is today. We draw upon the findings of the HarmoniCOP national reports to identify common features and cultural differences. We depart from the traditional ideational concept of culture as a long-lasting system of perceptions, beliefs, norms, and values to provide a detailed discussion of the practices in four countries. We demonstrate that culture is just one of the factors that explain the differences in national approaches to public participation and argue that culture perceived as a more dynamic, integrated, adaptive socio-cultural system in which groups of actors create new frames, norms, and routines is a more promising road for further research.
\end{abstract}

Key Words: culture; public participation; river basin management planning

\section{INTRODUCTION AND BACKGROUND}

Environmental management policies in Europe stretch back over past decades, whereas policies that explicitly recognize the need for the promotion of public participation in environmental management have only been implemented in more recent years. The ambitiously formulated public participation provisions of the European Water Framework Directive (WFD) need to be considered in the context of international and European developments that advocate the involvement of a wide range of actors in decision making in natural resource management. Considerable advancements have taken place in recent years; these were most prominently taken up by the United Nations Economic Commission for Europe Aarhus Convention on Access to Information, Public Participation in Decision-making, and Access to Justice in Environmental Matters, which entered into force in 2001 (http://www.unece.org/env/pp/do cuments/cep43e.pdf). This convention provides for fairly detailed provisions to ensure the public participation rights of individuals and organizations according to three distinct "pillars": access to environmental information; public participation in decisions on specific activities, particularly plans, programs, and policies relating to the environment; and access to justice.

Individual nations have considerably different public participation problems and approaches. This was particularly evident during negotiations among the European countries leading up to the development of the WFD (Scott and Holder 2006); there was differing support for the public participation provisions of the WFD among the member states. Considering the significantly different historical, political, and cultural backgrounds and experiences of the member states, 
considerable challenges in implementing the public participation requirements were to be expected. At the same time, cooperation between nations in relation to transboundary basins is necessary to deliver the objectives of the WFD. This explains the importance focusing on understanding broad national cultural trends and (sub)cultures that have distinguished or united nations and continue to do so.

Most research on the meaning of culture for participation in decision-making processes has focused on participative decision making, a domain that is almost exclusively devoted to the business realm. These studies have mainly focused on the behaviors that are necessary to become a successful business partner (e.g., Hofstede 1991, 2001, Bass 1996, Heller et al. 1998) and on managing diversity in business environments (e.g., Harvey and Allard 2002). With respect to the business realm, Hofstede (2001:109) argues, "One cannot write meaningfully about organizational participation without embedding it within a national cultural context." Here, we explore whether the same holds for public participation in river basin management. Because little research has been done on this specific subject, we are well aware that our research is exploratory in character. Moreover, the data collected by the HarmoniCOP national reports on river basin management are historically and ethnographically comparative in character, rather than quantitative. Consequently, we present our findings and recommendations as hypotheses, rather than conclusions, regarding design requirements for public participation in river basin management.

The HarmoniCOP national reports collected a great deal of the knowledge and experience on public participation in river basin management planning that is enshrined within the histories of the nine participating European countries of the HarmoniCOP project: Belgium, France, Germany, Hungary, Italy, the Netherlands, Spain, Switzerland, and the UK. These experiences were described and analyzed in the National Approach and Background studies of public participation in river basin management planning in Europe (Enserink et al. 2003, Iijas and Botond 2003, Kampa et al. 2003, Lebourhis 2003, Maestu 2003, Massarutto et al. 2003, Simeoni 2003, Tunstall and Green 2003, Van Rossen 2003). The national reports provide insights into the national public participatory experiences and traditions and the influences of institutional, legal, cultural, and geographical/physical factors on river basin management planning. Collectively, they provide a basis for comparing and understanding the different political and historical trends of public participation in river basin management planning that exist across Europe.

A jointly created terms-of-reference document provided guidance for the national teams (http://ww w.harmonicop.uos.de/). The terms of reference provided standardized research criteria that allowed the effective and consistent comparison of the different national approaches and the identification of the underlying reasons for these differences. Important research assignments in the terms of reference were the description of significant historical facts, political culture, policy support, institutional setting, and the country's experience with public participation, especially public participation in river basin management. From the start, it was clear that on-line research or literature reviews alone would not suffice and needed to be supplemented by on-site research and face-to-face interviews to enrich the context of the individual studies. A synthesis report (Patel and Stel 2004) was compiled with the specific aim of organizing and highlighting common features and cultural differences, as well as drawing together other key considerations presented within the nine individual reports. The comparison, analysis, and synthesis of national experiences also served a very practical purpose because many European river basins are transboundary basins, requiring far-reaching international cooperation, especially in the area of public participation. The development of cooperation will be helped greatly by the increased knowledge and understanding of the different national and regional approaches to public participation and their cultural backgrounds and contexts.

In the next two sections, we define and delineate the concepts of public participation and culture. We then draw from the findings of some of the HarmoniCOP national reports; by honoring historical roots, we attempt to frame differences in national practices within cultural theory. In the final section, we formulate some conclusions and recommendations for the implementation of the WFD based on the acquired insights. 


\section{PUBLIC PARTICIPATION}

Public participation may be defined as the involvement of individuals and groups that are positively or negatively affected by or are interested in a proposed intervention, e.g., a project, program, plan, or policy, that is subject to a decision-making process (André et al. 2006). Public participation is both a prerequisite and an element of good governance and the sustainable management of natural resources (UNESCAP 2005, Enserink 2006, Enserink and Koppenjan 2007). Several international organizations provide extensive guidance, rules of engagement, best practices principles, and core values for the practice of public participation (e.g., International Association for Public Participation, http://www.iap2.org/; International Association for Impact Assessment, http://www.iaia.org/; The World Bank handbook on public participation, http://rr u.worldbank.org/Toolkits/PublicPrivatedialogue/).

Public participation and culture are intertwined; national, local, and professional cultures and their formal institutions co-determine the level and methods of public participation. Although management scholars recognize the sociocultural environment as one of the most influential factors that explains how culture affects behavior in organizational settings (Almond and Verba 1963, Sagie and Aycan 2003), relatively little systematic research has been done to examine the relation between culture and public participation in natural resource management.

\section{CULTURE}

One of the earliest definitions of culture was given by Kroeber and Kluckhohn (1952:181): "Culture consists of patterns, explicit and implicit, of and for behavior acquired and transmitted by symbols, constituting the distinctive achievements of human groups, including their embodiments in artifacts; the essential core of culture consists of traditional (i.e., historically derived and selected) ideas and especially their attached values." In the literature, the core ideas and attached values are often depicted as the deep layers and the visible outside, respectively, of an onion (Hofstede et al. 1990, Sanders and Neuijen 1999). The elements in each layer may change over time, but the deeper core values often are stable across generations and relatively impermeable to the passage of time (Hofstede 2001, Rao 2002). In the same tradition,
Schein (1992) identified three distinct levels in organizational cultures: artifacts and behaviors, espoused values, and assumptions.

Keesing (1974) distinguished between culture as an ideational system and culture as an integrated adaptive socio-cultural system. The former case refers to perceptions, beliefs, and norms; culture is viewed as a relatively stable concept that stems from early socialization in childhood and at school (e.g., Hofstede 1991) and is both an individual and social phenomenon. According to Lie (2003, in press), this type of socio-psychological approach uses mainly quantitative methods to search for collective characteristics and universal generalizations to facilitate comparative research. The latter case refers to social group characteristics that result from the interaction of the group's members; it is a dominant perspective in anthropological theories and schools. In this case, culture as an integrated system is a characteristic of a group, which may be much smaller than society as a whole. Because people can participate in different groups, they can also participate in different cultures.

The main category for analysis in the ideationalist approach is the nation state. In western European ideologies, nation is defined as a political community of individual citizens enjoying equal rights by virtue of their permanent attachment to the given state's territory (Amato and Batt 1999). The ideationalist concept of culture is rather static, although changes do occur, as indicated by international comparative trend studies by Inglehart and Welzel (2005). The Cultural Map of the World (http://margaux.grandvinum.se/SebTest/wvs/articles/ folder published/article base 54) shows worldwide movement toward a more secular-rational and selfexpression oriented cultural orientation. Inglehart and Welzel claim that their World Values Surveys ( http://margaux.grandvinum.se/SebTest/wvs/index surveys ) provide a comprehensive measurement of all major areas of human concern, from religion to politics to economic and social life, based on just two dimensions: traditional/secular-rational values and survival/self-expression values.

However, Hofstede (1991) stressed that culture should strictly be considered in the context of societies, rather than nations. This is particularly important because each society or group has its own (sub)culture. Inhabitants of one country do not necessarily form one group with its own culture. Also, other groups such as local groups, disciplines, 
and organizations possess such (sub)cultures. Similarly, Pahl-Wostl et al. (2007) argue that the identity or carrier of a culture may differ, e.g., nation state, region, societal group, or corporation. They state that the carrier of a culture is not necessarily identical with all of the people that share the same nationality and point out that regional cultures transcend national boundaries.

In practice, in the case studies presented in each of the HarmoniCOP national reports, neither cultural dynamics nor intercultural communication were at the heart of these mostly historical institutional analyses. Consequently, it is the extent to which traditional historical values and institutions and their embedded (national) cultures co-determine the new public participation culture in international river basin management that was central to our enquiry.

Although we argue for awareness of regional cultural differences and dynamics, we chose to use Hofstede's $(1991,2001)$ dimensions of national cultures to frame the role of (national) culture in the analysis of the various national experiences with public participation in different countries. Hofstede's $(1991,2001)$ dimensions, which we describe in the next section, provide a framework for comparing broader national cultures that fits better to our empirical material than do the two dimensions of Inglehart and Welzel (2005). Our aim was not to decide what is the best conceptualization of culture, but the concept was necessary to help in the formulation of design requirements for effective participation and international cooperation in river basin management. We use Hofstede's $(1991,2001)$ dimensions and the scores of various countries on his dimensions (http://www.geert-hofstede.com/ge ert hofstede resources.shtml) to corroborate our empirical findings. The point to appreciate here is the importance of a cultural focus in the consideration of river basin management planning at multiple scales within and between countries. We could also have used the Inglehart and Welzel (2005) approach, as used in the World Values Surveys, but that would have restricted us to a distinction between catholic and protestant, which is not relevant because most countries in our sample have mixed populations and score relatively high on the secular-rational axis. Such a pragmatic, opportunistic, or strategic use can be legitimized by referring to Smircich (1983) and Allaire and Firsirotu (1984), who promoted the culture concept and cultural theories as a source of inspiration for management and organizational theories. Hofstede (1991, 2001) uses five dimensions to classify countries and make cultural differences tangible:

- Power distance, which is expressed as the power distance index. It is a measure of the degree of equality or inequality in a society;

- Individualism/collectivism, which indicates whether individual or collective rights are prominent;

- Masculinity, which is the degree to which society reinforces the traditional masculine work role model of male achievement, control, and power;

- Uncertainty avoidance, which is the level of tolerance for uncertainty and ambiguity. If it is high, a country has a low tolerance for uncertainty and ambiguity and is rule oriented to reduce the amount of uncertainty; this is typical of Catholic countries; and

- Long-term orientation, which reflects the degree to which society embraces long-term devotion to tradition versus forward-thinking values. If it is low, change can occur rapidly.

As Schein (1992) pointed out, one should bear in mind that only statements on specific elements or dimensions of culture can be made, and culture cannot be explained as an entity. For practical reasons, we focused on the UK, the Netherlands, and Germany. One of the cases treated in the Netherlands report was transboundary and thus involved Belguim. We also discuss the Spain report because Spain and Germany have a comparable history of radical political/system change. These five countries were assigned scores for Hofstede's five dimensions (Table 1).

\section{CHARACTERISTICS OF PUBLIC PARTICIPATION IN FOUR EUROPEAN COUNTRIES}

Although it did not really become manifest officially until the 20th century, public participation was evident in European water management and 
Table 1. Country scores for Hofstede's five cultural dimensions. Source: http://www.geert-hofstede.com/ geert hofstede resources.shtml.

\begin{tabular}{lccccc}
\hline \hline & & \multicolumn{5}{c}{ Cultural dimension } \\
\cline { 2 - 6 } & Power distance & $\begin{array}{c}\text { Individualism/ } \\
\text { collectivism }\end{array}$ & Uncertainty avoidance & Masculinity & Long-term orientation \\
\hline United Kingdom & 35 & 89 & 35 & 66 & 25 \\
Netherlands & 38 & 80 & 53 & 6 & 44 \\
Germany & 35 & 67 & 65 & 66 & 31 \\
Spain & 57 & 51 & 86 & 42 & no data \\
Belgium & 65 & 75 & 94 & 54 & no data \\
\hline
\end{tabular}

planning practices much earlier. The Netherlands and Spain provide good examples in which water management has been of vital significance historically because of specific environmental conditions, i.e., the threat of flooding and water scarcity, respectively. In both countries, the importance of public participation has been recognized for centuries and has resulted in institutionalized systems for the collective management of water resources (Enserink et al. 2003, Maestu 2003). In some other EU countries such as Italy, the UK, France, and Belgium, and especially in the newly joining countries, public participation has only become more evident over the past few decades (Patel and Stel 2004). The UK is historically characterized by centralized institutions and decisions made largely at the central government level (Tunstall and Green 2003). In Germany, attention for public participation in the management of public goods began at the turn of the 20th century and grew to its current status during the period of industrialization. According to Kampa et al. (2003), in the 1970s, increased public awareness of the negative effects of river pollution resulted in extensive environmental legislation that served to increase public participation, creating a more favorable climate for the development of environmental stakeholder groups in Germany. Highly interesting in Germany are the historical and political differences between the former East and West Germany. In the Netherlands, a great deal of attention was first given to public participation in the 1960s because of building public pressure. This was predominantly fuelled by the view of public participation as a means to improve decision making and increase the legitimacy of public policy making. Comparable mechanisms can be observed elsewhere such as in Hungary, although there, the recognition of public participation only came about in the 1980s (Ijjas and Botond 2003). Other important drivers were the fear of natural environmental disasters (e.g., in Switzerland) or the recognition of the key importance to economic modernization of the maintenance and protection of water resources (Simeoni 2003).

\section{United Kingdom}

In the UK, it has not been until the most recent policy initiative, the Catchment Abstraction Management Strategy (CAMS), that convincing efforts to support stakeholder involvement could be identified. Although still in its early stages, the CAMS aims to provide a consistent and structured approach to local water resource management, providing a promising alternative to past approaches, as well as valuable experience in establishing and working with stakeholder groups within the Environment Agency (Tunstall and Green 2003). In many ways, the CAMS guidance could serve as a model for the Water Framework Directive (WFD) process. 
Nevertheless, the CAMS still fails to meet all of the requirements set by the WFD; for instance, the requirement for the active involvement of stakeholders is still relatively weak. However, more dynamic, innovative, and interactive participatory experiences have been supported and facilitated through such policies as Local Agenda 21 (Tunstall and Green 2003).

The UK is an example of a strong centralized system within which direction and control is contained within the confines of the central government, leaving very little power for decision making, action, and revenues at the local level. According to Lutz and Linder (2002), such a system simply defies the need for participatory arrangements at the local level. Moreover, increased privatization in the UK during the 1980s and 1990s resulted in increased obtacles for public participation in that the citizen became the customer. Thus, when the water industry was privatized, the public was converted from a client of a public service to an actual customer of profit-making corporations. Ultimately, this redefinition of the citizen prevented the public from having any involvement in the decision-making process. Further analysis of the political system in the UK reveals that certain features constrain the ability of the UK to easily adopt the structures necessary for public participation. The UK remains committed to its legacy of having invented modern democracy and is particularly proud of its representative democracy. However, this representative democracy clashes somewhat with the participatory agenda as outlined by the Aarhus Convention and other such strategies. This is largely because elected representatives, at both the national and local levels, claim legitimacy and thus view public participation as in conflict with their role of representing the public that elected them. Other forces that maintain the centralized UK political style are nongovermental organizations that support the centralized approach because they find it easier to lobby and exert their influence upon one central government department than upon various public stakeholders.

\section{Germany}

To avoid oversimplification, it is necessary to consider an alternative European example of a currently federal political system. The case of Germany offers an interesting perspective because it comprises two very different legacies in terms of public participation that continue to have a decisive influence on public participation today. In former West Germany (Federal Republic of Germany), there was a rather long tradition and notable record of participatory activity in water management. Relevant actors in water management, as well as in other areas of environmental policy, have been and continue to be fairly well organized and established. In fact, public participation has largely been realized through the involvement of organized stakeholder groups, which is largely because procedures in the context of formal planning consultations and active involvement initiatives are geared toward these groups, rather than the general public. This approach continues to be followed today and is currently being adapted to the exigencies of WFD implementation.

In former East Germany (German Democratic Republic [GDR]), state-society relationships prior to reunification in 1990 were dominated by a topdown approach in decision making, largely because of the centralized approach to decision making. In today's federal Germany, and especially in those Länder (states) formerly under GDR rule, the East German culture as formed through the 40-yr GDR regime still shows its influence through the low value it assigns to public participation, ultimately leading to a low level of public participation in water management issues in practice. At present, the Länder in former East Germany face a much bigger challenge than those in former West Germany in accommodating the participatory spirit of river basin management as required by the WFD because they lack the experience and necessary cultural background. Since the inception of the WFD, it has become evident that the implementing authorities in former East Germany are faced with significantly different conditions from those in former West Germany, which partly relate to cultural differences.

The dichotomy between former East and West Germany in terms of initiating public participation to facilitate WFD implementation could be perceived as evidence for the relevance of power distance in conjunction with individualism in enabling public participation. In former West Germany, which could be described as a more individualistic culture, citizens' initiatives to raise issues such as water pollution have lead to the continual development of environmental awareness, as well as the regular and broad-based involvement of stakeholders on such issues, which was eventually also embedded in institutional structures. Among other factors, the high power distance and 
less individualistic culture in former East Germany might have contributed to the suppression of such development and to the formation of underground environmental groups that have limited access to environmental information and no access to decision-making processes.

These cultural differences that are enshrined in the different historical development trajectories of former West and East Germany have been propagated until today and might serve as an explanation for difficulties in addressing public participation requirements for WFD implementation. However, it should not be overlooked that challenges are brought about by the West German system as well, which relies greatly on organized stakeholder groups and places strong emphasis on consultation, rather than active participation. Furthermore, other cultural aspects such as different water management paradigms in the different Länder also play a significant role. In this context, since the WFD entered into force, very different regional approaches have been taken by individual Länder in terms of public participation. These differences are only partly related to the legacies of the two German regimes and represent the results of dynamic development over the past $15 \mathrm{yr}$.

\section{The Netherlands}

The liberal political structure and decentralized government institutions in the Netherlands identify a political culture that would appear to provide favorable conditions for public participation. The centuries-old water boards are considered to be the basis for the so-called Dutch "consensus culture" or "polder model." More specifically, they strongly favor the reaching of agreements and aim for the prevention of conflicts rather than the application of authoritative solutions and hierarchical decision making. Such a decentralized approach to decision making suggests promising conditions for the wider implementation of public participation. The relatively low power distance and high individualism rankings for the Netherlands (Table 1) seem to corroborate this preference for consensus building. However, Dutch politicians have also heavily criticized this consensus culture in favor of formal representative democratic institutions to make firm and timely decisions. During the 1990s in particular, influential advisory committees suggested that the national government speed up decision making on large infrastructure projects while at the same time involving stakeholders more intensively and especially earlier in the process (Lambers et al. 1994, Wetenschappelijke Raad voor het Regeringsbeleid 1994). Consequently, it became almost standard practice to obtain the participation of stakeholders in so-called open planning processes, and market parties and social organizations have become serious partners in public infrastructure planning. Two cases described in the national report, i.e., Meer Visie, initiated by Rijkswaterstaat, the national (governmental) agency for water management, and ABCDelfland, organized by the regional water board Delfland, are examples of extensive stakeholder consultation and even some co-production. In both cases, regional and local authorities and representatives of organized stakeholder groups such as environmental and recreational interest groups were invited to actively participate in workshops to express their views. This contrasts greatly with the situation in Germany. These two cases, however, contrast with the third case in the Netherlands national report, $i$. e., the Long-term Vision for the Scheldt, in which a process was set up with the involvement of mainly high-level officials and bureaucrats, and, except for representatives of the harbor of Antwerpen, little stakeholder participation. The Scheldt is a transboundary basin and this nonparticipation was obviously related to the historical disputes between Flanders (Belgium) and the Netherlands and the large differences in tradition and experience with public participation between Flanders and the Netherlands. The project was a success because an agreement was reached between the two governments on deepening the Scheldt and on nature compensation; a culture of cooperation emerged, and trust and respect were built up between the historical rivals. However, the project was a failure with respect to the creation of support for the Long-term Vision in the Netherlands because regional and local authorities objected to the plans and local action groups seized the front pages of the newspapers. Cultural factors like the much higher power distance and uncertainty avoidance scores in Belgium than in the Netherlands can explain much of these differences in the national approaches.

Despite the above examples, the water sector within the Netherlands is considered to be quite technocratic in character and pragmatic in its public participation approach. There is an expert bias within the water boards and especially within Rijkswaterstaat. Moreover, the official government policy for implementing the EU WFD is pragmatic 
implementation, which, according to the Deputy Minister of Transport, Public Works, and Water Management, means that very targeted meetings on specific themes for the relevant organizations involved will be planned (Kamerstukken II 20032004). In practice, this means that organized interest groups will be invited to comment on the river basin management plans in their respective stages of preparation (Enserink 2005). Until now, the Dutch track-record has been poor; there has been neither stakeholder nor public involvement in the classification of river basins and sub-basins.

\section{Spain}

Spain has experienced an ongoing period of increasing decentralization and is an example in which the current state of affairs has grown from the political culture and historical institutional setting of river basin management. In the early 1900s, participatory River Basin Administrations (RBAs) were created as self-administrated organizations, with user participation organized through syndicates (associations of economic interests). During the post civil war dictatorship, these RBAs were abolished and substituted by nonparticipatory, state-run organizations that were used as instruments by the central government. This movement reversed the historical participatory nature of river basin management in Spain. The government domination of river basin management and water resource development and planning means that water is often perceived by the public as a state problem, belonging to no one or to anyone (Maestu 2003). During the democratization and decentralization period after 1978, participation in RBAs opened up and new interests were given a greater role; these were mainly environmentalist groups and regional governments, but also scientific experts. Toward the end of the 20th century, this led to further decentralization toward the creation of regionally managed river basins. Swyngedouw (1999) described Spain's political decentralization process and the central role of water politics and engineering in Spain's modernization process. He referred specifically to the importance of competition among the regions of Spain and also to increased competition between regional and central governments. The fierceness of the debate between center and region can be retraced to the relatively high power distance scores for Spain (Table 1). It could be argued that as a typical Catholic country with high power distance and a clear preference for uncertainty avoidance, these cultural characteristics explain the resistance against decentralization and stakeholder participation.

General public interests have mainly remained indirectly represented by the public authorities (Patel and Stel 2004). The direct participation of citizens in planning processes occurs mainly through formal public information and allegation processes (Maestu 2003). It was not until the implementation of the WFD in 2003 that a more integrated conception of public participation in the RBAs was finally incorporated. The Spain example illustrates that public participation in decision making is highly dependent upon how the decentralization process is undertaken, i.e., how the decision-making process is structured and how the institutions and the process fit in a given environment and to the political situation in general (Lutz and Linder 2002).

\section{HYPOTHESES ON PUBLIC PARTICIPATION IN A CULTURAL CONTEXT}

We have argued that one cannot write meaningfully about public participation in river basin management without embedding it in a national cultural context. We have also attempted to relate important national trends and practices to cultural theory. However, we should be careful not to claim to be as thorough and quantitative as Hofstede (2001), let alone as disciplined as advocated by Schein (1992); our research findings are mostly historical and qualitative and are based on case reconstructions and expert judgments. Consequently, we present our findings as hypotheses regarding possible explanations for the observed phenomena.

According to Sagie and Aycan (2003), power distance and individualism are strongly correlated with participation in in-company decision making. We hypothesize that power distance also influences the extent to which public participation in river basin management planning is practiced; high power distance allows for more authoritative top-down decision making with little participation, and our case material suggests that low power distance and egalitarianism coincide with the inclination toward participation and active involvement. Similarly, in individualistic societies, individual rights govern behavior, and individuals will stand up to defend their rights, thus spurring participation in political 
decision making. These effects are clearly illustrated for the situation in the UK and by the differences between former East and West Germany and between Flanders and the Netherlands in the Scheldt case.

Nonetheless, the relation between power distance and participation is less obvious than suggested here. In the Netherlands and Germany, the egalitarian character coincides with relatively high levels of participation in water management, but so is the case in Spain, which has a relatively high power distance index. The individualism index seems troublesome too, as both the Netherlands and especially the UK have high scores, whereas historically only the Netherlands has had extensive public participation in water management. Comparatively, in the UK water sector, public involvement in planning and management has only recently begun to be considered. The important change in direction in UK river management policy came about in the 1990s, when the Environment Agency finally recognized the need to promote public awareness and self help among those at risk and enabled this through the publication of indicative flood plain maps on the internet. Although the UK scores for power distance and individualism compare to those of Germany and the Netherlands, Tunstall and Green (2003) recognized that the UK institutions and culture under current conditions are simply not conducive to the development of public participation. The only dimension in which the UK clearly deviates from Germany and the Netherlands is uncertainty avoidance, which, in combination with the high score for individualism, might explain the easy acceptance of the privatization of the water industry.

Water management has also played a prominent role in German history, and public participation in water management has been important since the 18th century. It was the first policy area to consider the interests of stakeholders. Denmark and the Netherlands are both neighboring countries of Germany and are quite similar to Germany in the aspect of power distance; however, in Hofstede's framework, Denmark and the Netherlands are slightly more individualistic and much less masculine than is Germany. In the latter dimension, Denmark and the Netherlands are similar to most Nordic countries. This suggests that masculinity might be another factor that influences a country's inclination toward public participation because the pace and extent of public participation activities in
Germany is assessed as somewhat lagging behind the levels of its neighbors. When the masculinity score is combined with high scores for power distance, as in the case of Spain and Italy, it seems to inhibit public participation; the situation in Flanders seems to corroborate this finding.

We derived four hypotheses from the above empirical findings:

- A high power distance index is not conducive to public participation;

- Individualism is not a determining factor for the extent and success of public participation in a country;

- Collectivism facilitates a high degree of public participation, but this may be left to informal processes if the power distance is high; and

- A high masculinity score is not conducive to public participation.

Another interesting observation is that many Catholic countries tend to have both a high power index and a high uncertainty avoidance score. Spain and Belgium are such examples, and their scores compare to those of Italy. Belgium (Van Rossen 2003) and Italy (Massarutto et al. 2003) show evidence of high central control and little room for the delegation of power. Clearly, uncertainty avoidance is a factor that strengthens resistance against change and consequently inhibits new forms of public participation in river basin management planning. Historically, Spain seems to be an exception, but the situation in the other countries leads to a fifth hypothesis:

- High power distance and high uncertainty avoidance inhibit public participation because they support centralized and controloriented systems of water management.

In Spain, the high power distance and strong central government system and style, as in France as described in the Dordogne case study (Barraqué et al. 2004), can even lead to no possible responses other than public demonstrations, as was the case in 
Spain with the National Hydrological Plan. The public struggle has consequently been conducted outside the institutional framework and on the streets. Although such forms of public participation are very powerful means by which citizens can express their opinions, unless they result in citizens' access to decision making and evolve toward more inclusive and cooperative relations, they will remain obstacles to social learning. This is important because it illustrates that institutional design in any governing system in any country needs to take into account the forms and characteristics of various types of public participation to accommodate the cultural context of that country.

\section{CONCLUSIONS: CONSIDERATIONS FOR THE IMPLEMENTATION OF THE WATER FRAMEWORK DIRECTIVE}

Our analysis was based on the nine National Approach and Background studies of the EU HarmoniCOP project. Consequently, differences in national cultures from the ideationalist perspective have been our point of departure, but the empirical evidence suggests that this perspective is insufficient to explain the complex interrelation between public participation and political culture. Clearly, culture is a more dynamic concept than traditional ideationalists maintain. We even suggest that in a highly dynamic political environment such as the rapidly expanding EU, new practices and institutions and accompanying new (sub)cultures are formed continuously and existing ones grow and change daily. To analyze the role of culture in such a dynamic context, a more postmodern, interpretative, and ethnographically based approach featuring spaces of intercultural communication, as promoted by Lie (2003, in press), seems better fit for exploring the effects of culture in river basin management.

Nonetheless, using the cultural dimensions as defined by Hofstede $(1991,2001)$, we found some elements that could explain the differences and commonalities in public participation practices in river basin management planning in various European countries and formulated a number of hypotheses regarding the influence of large power distance in inhibiting participation and the reinforcement of this tendency by large power distance in combination with either high uncertainty avoidance and/or masculinity scores. At the same time, various examples illustrated that culture cannot explain differences in absolute terms; factors such as national history, practical experience, and existing political and institutional settings also play important roles and may lead to different and sometimes seemingly contradictory behavior.

In Germany, the determining element in shaping participatory processes in addition to culture, as framed during the time of the division of Germany, appears to be the respective institutional structures of the individual Länder governments. Also, the case of Germany displays indications of the phenomenon of cultural dynamics, which in recent years has lead to a variety of approaches combining formal and informal arrangements. The lessons are that cultural factors are only one of the factors that determine the success or failure of public participation practices and that the concept of culture contributes to the explanation of the presence or absence of a tradition of public participation in policy making because it is intertwined with history and politics. Consequently, when designing public participation programs and when institutionalizing public participation, for instance, for international river basin management planning, it is important to accommodate the cultural context.

A general finding is that cultures that are characterized by high power distance and high masculinity are unlikely to embrace public participation. Cultures that have a tendency to avoid uncertainty and countries that are characterized by collectivist cultures, like most of the Mediterranean countries, can build upon their existing experiences to implement EU requirements, but will have to make considerable efforts to link informal and formal decision-making processes. The examples from Spain and the UK are indicative of high power distance, in which traditionally little decisionmaking power is transferred to the public. They highlight the vulnerability and challenge the longterm adoption and integration of public participation in river basin management. More specifically, they draw attention to the less controllable political challenges that can critically and potentially serve to weaken any policy or legislation that aims to operate as a lever to enforce public participation within planning processes. These findings on the limited but real influence of cultural factors on the success and failure of public participation seem to be of a general character and therefore should be considered important input in designing successful public participation schemes. 
Responses to this article can be read online at:

http://www.ecologyandsociety.org/vol12/iss2/art24/responses/

\section{Acknowledgments:}

We express our gratitude to two anonymous referees for their insightful and constructive comments.

\section{LITERATURE CITED}

Allaire, Y., and M. E. Firsirotu. 1984. Theories of organizational culture. Organization Studies 5 (3):193-226.

Almond, G. A., and S. Verba. 1963. The civic culture. Political attitudes and democracy in five nations. Princeton University Press, Princeton, New Jersey, USA.

Amato, G., and J. Batt. 1998. Minority rights and EU enlargement to the east. Report of the first meeting of the reflection group on the long-term implications of EU enlargement: the nature of the new border. RSC Policy Paper Number 98/5. European University Institute, Florence, Italy. Available online at: http://www.eui.eu/RSCAS/WPTexts/98 05p.htm.

André, P., B. Enserink, D. Connor, and P. Croal. 2006. Public participation international best practice principles. Special Publication Series Number 4. International Association for Impact Assessment, Fargo, North Dakota, USA. Available online at: http://www.iaia.org/modx/assets/files/SP4\% 20web.pdf.

Barraqué, B., J.-P. Le Bourhis, P. Maurel, and R. Raymond. 2004. Public participation in the Dordogne River basin. Report of work package 5 of the HarmoniCOP project. Available online at: http://harmonicop.info/ files/ down/Final\%20WP5\% 20French\%20Case\%20Study\%20Report\%2029Nov\% 2004.pdf.

Bass, B. M. 1996. Decision-making and organizational culture. Pages 169-179 in P. J. D. Drenth, P. L. Koopman, and B. Wilpert, editors. Organizational decision-making under different economic and political conditions: proceedings of a symposium at the Royal Netherlands Academy of Arts and Sciences on 1-3 June 1994. North-Holland, Amsterdam, the Netherlands.

Enserink, B. 2005. Public participation in Dutch watermanagement: pragmatism in meeting EU requirements. Pages 203-227 in P. H. Feindt and J. Newig, editors. Partizipation, Öffentlichkeitsbeteiligung, Nachhaltigkeit. Perspektieven der Politischen Ökonomie. Ökologie und Wirtschaftsforschung. Volume 62. Metropolis-Verlag, Marburg, Germany.

Enserink, B. 2006. The ants in the kingdom of elephants. An explorative study into public participation in policy making in India and China. Proceedings of the XVI World Congress of Sociology (23-29 July 2006). ISA 2006 Congress, Durban, South Africa.

Enserink, B., D. Kamps, and E. Mostert. 2003. Public participation in river basin management in the Netherlands: (not) everybody's concern. Report of workpackage 4 of the HarmoniCOP project. Available online at: http://www.harmonicop.uni-os nabrueck.de/ files/ down/Netherlands.pdf.

Enserink, B., and J. Koppenjan. 2007. Public participation in China: sustainable urbanization and governance. Management of Environmental Quality: an International Journal 18(4):459-474.

Harvey, C. P., and M. J. Allard, editors. 2002. Understanding and managing diversity: readings, cases, and exercises. Prentice Hall, Upper Saddle River, New Jersey, USA.

Heller, F., E. Pusic, G. Strauss, and B. Wilpert. 1998. Organizational participation: myth and reality. Oxford University Press, Oxford, UK.

Hofstede, G. 1991. Cultures and organizations: software of the mind. McGraw-Hill, London, UK.

Hofstede, G. 2001. Culture's consequences: comparing values, behaviors, institutions, and organizations across nations. Second edition. Sage Publications, Thousand Oaks, California, USA.

Hofstede, G., B. Neuijen, D. Ohayy Daval, and G. Sanders. 1990. Measuring organizational cultures: a qualitative and quantitative study across twenty cases. Administrative Science Quarterly 35 (2):286-316. 
Ijjas, I., and K. M. Botond. 2003. Towards winwin solutions: public participation in river basin management in Hungary. Report of workpackage 4 of the HarmoniCOP project. Available online at: http://www.harmonicop.uni-osnabrueck.de/ files/ down/ Hungary.pdf.

Inglehart, R., and C. Welzel. 2005. Modernization, cultural change, and democracy: the human development sequence. Cambridge University Press, Cambridge, UK.

Kamerstukken II. 2003-2004. Pragmatische implementatie Europese kaderrichtlijn water in Nederland: van beelden naar betekenis. 28808, Number 12. The Hague, the Netherlands. Available online at: http://www.europadecentraal.nl/documents/ dossiers/milieu/publicaties/KRW pragmatische implementatie.pdf?PHPSESSID=faac629a840fbd 1 3ab15f964054b1c4b.

Kampa, E., N. Kranz, and W. Hansen. 2003. Public participation in river basin management in Germany: from borders to natural boundaries. Report of workpackage 4 of the HarmoniCOP project. Available online at: http://www.harmonicop. uni-osnabrueck.de/ files/ down/Germany.pdf.

Keesing, R. 1974. Theories of culture. Annual Review of Anthropology 3:73-97.

Kroeber, A. L., and C. Kluckhohn. 1952. Culture: a critical review of concepts and definitions. Peabody Museum, Cambridge, Massachusetts, USA.

Lambers, C., D. A. Lubach, and M. Scheltema. 1994. Versnelling juridische procedures grote projecten. Sdu Publishers, The Hague, the Netherlands.

Lebourhis, J. P. 2003. Public participation and the European Water Framework Directive: developing water citizenship. French national report. Report of workpackage 4 of the HarmoniCOP project. Available online at: http://www.harmonicop.uni-os nabrueck.de/ files/ down/France.pdf.

Lie, R. 2003. Spaces of intercultural communication: an interdisciplinary introduction to communication, culture, and globalizing/localizing identities. Hampton Press, Creskill, New Jersey, USA.
Lie, R. In press. Intercultural communication: a field of study. In C. del Valle and J. Moreno, editors. Communicación intercultural. Genealogía, Crítica y Perspectivas. Instituto Europeo de Communicación y Desarollo, Seville, Spain.

Lutz, G., and W. Linder. 2002. Democracy and participation: solutions for improving governance at the local level. Paper for the World Bank Workshop on Intergovernmental Fiscal Relations in East Asia (10-11 January 2002). Bali, Indonesia. Available online at: http://info.worldbank.org/etools/ docs/library/39264/ Pr sentation\%20Lutz\%20Linder\% 20WB\%20Workshop\%20trad\%20authorities\%20intro. ppt.

Maestu, J., editor. 2003. Public participation in river basin management in Spain: reflecting changes in external and self-created context. Report of workpackage 4 of the HarmoniCOP project. Available online at: http://www.harmonicop.uni-os nabrueck.de/ files/ down/Spain.pdf.

Massarutto, A., A. de Carli, C. Longhi, and M. Scarpari. 2003. Public participation in river basin management planning in Italy: an unconventional marriage of top-down planning and corporative politics. Report of workpackage 4 of the HarmoniCOP project. Available online at: http://w ww.harmonicop.uni-osnabrueck.de/ files/ down/Italy. pdf.

Pahl-Wostl, C., R. Bouwen, M. Craps, A. Dewulf, E. Mostert, D. Ridder, D. Tàbara, and T. Taillieu. 2007. The importance of social learning and culture for sustainable water management. Ecological Economics, in press.

Patel, M., and J. H. Stel, editors. 2004. Public participation in river basin management in Europe: a national approach and background study synthesising experiences of 9 European countries. Report of workpackage 4 of the HarmoniCOP project. Available online at: http://www.harmonicop. uni-osnabrueck.de/ files/ down/WP4SynthesisReport. pdf.

Rao, A. 2002. Religion, culture, and management in the new millennium. Pages 149-157 in C. P. Harvey and M. J. Allard, editors. Understanding and managing diversity: readings, cases, and exercises. Prentice Hall, Upper Saddle River, New Jersey, USA. 
Sagie, A., and Z. Aycan. 2003. A cross-cultural analysis of participative decision-making in organizations. Human Relations 56(4):453-473.

Sanders, G., and B. Neuijen. 1999. Bedrijfscultuur, diagnose en beïnvloeding. Van Gorcum Press, Assen, the Netherlands.

Schein, E. H. 1992. Organizational culture and leadership. Second edition. Jossey-Bass, San Francisco, California, USA.

Scott, J., and J. Holder. 2006. Law and new environmental governance in the European Union. Pages 211-241 in G. de Búrca and J. Scott, editors. Law and new governance in the EU and the US. Hart Publishing, Oxford, UK.

Simeoni, G. 2003. Public participation in river basin management in Switzerland: fighting against floods. Report of workpackage 4 of the HarmoniCOP project. Available online at: http://w ww.harmonicop.uni-osnabrueck.de/ files/ down/ Switzerland.pdf.

Smircich, L. 1983. Concepts of culture and organizational analysis. Administrative Science Quarterly 28:339-358.

Swyngedouw, E. 1999. Modernity and hybridity: nature, regeneracionismo, and the production of the Spanish waterscape (1890-1930). Annals of the Association of American Geographers 89 (3):443-465.

Tunstall, S., and C. Green. 2003. From listener to talker: the changing social role of the citizen in England and Wales. Report of workpackage 4 of the HarmoniCOP project. Available online at: http://w ww.harmonicop.uni-osnabrueck.de/ files/ down/UK. pdf.

UNESCAP. 2005. What is good governance? United Nations Economic and Social Comission for Asia and the Pacific, Bangkok, Thailand. Available online at: http://www.unescap.org/pdd/prs/ProjectA ctivities/Ongoing/gg/governance.pdf.

Van Rossen, E. 2003. Public participation in river basin management in Flanders (Belgium): towards more dynamism. Report of workpackage 4 of the HarmoniCOP project. Available online at: http://w ww.harmonicop.uni-osnabrueck.de/ files/ down/Belgium. pdf.
Wetenschappelijke Raad voor het Regeringsbeleid. 1994. Besluiten over grote projecten. Sdu Publishers, The Hague, the Netherlands. 